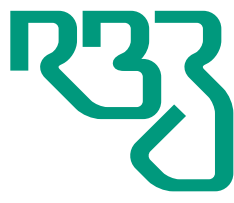

Revista

Brasileira de

Zootecnia

Brazilian Journal of Animal Science

ISSN 1806-9290

www.rbz.org.br

\section{Heritability estimation and genetic correlations for mature weight, visual scores, and growth traits in Nellore cattle}

\author{
Celso Koetz Junior ${ }^{1^{*}}$ (iD), Vanerlei Mozaquatro Roso² ${ }^{2}$ iD, Patricia da Cruz \\ Fávaro $^{1}$ (iD), Gabriel Ribas Pereira ${ }^{1}$ (iD, Marcelo Henrique Favaro Borges ${ }^{1}$ (iD), \\ Flávio Antônio Barca Junior ${ }^{1}$ (iD), Júlio Otávio Jardim Barcellos ${ }^{3}$ iD, Edson \\ Luis de Azambuja Ribeiro ${ }^{4}$ iD \\ ${ }^{1}$ Universidade Norte do Paraná, Arapongas, PR, Brasil. \\ ${ }^{2}$ GenSys Consultores Associados SS, Porto Alegre, RS, Brasil. \\ ${ }^{3}$ Universidade Federal do Rio Grande do Sul, Departamento de Zootecnia, Núcleo de \\ Estudos em Sistemas de Produção de Bovinos de Corte e Cadeia Produtiva, Porto Alegre, \\ RS, Brasil. \\ ${ }^{4}$ Universidade Estadual de Londrina, Departamento de Zootecnia, Londrina, PR, Brasil.
}

\author{
*Corresponding author: \\ celsokoetzjr@yahoo.com.br \\ Received: September 15, 2017 \\ Accepted: February 28, 2019 \\ How to cite: Koetz Junior, C.; Roso, V. M.; Fávaro, \\ P. C.; Pereira, G. R.; Borges, M. H. F.; Barca Junior, \\ F. A.; Barcellos, J. O. J. and Ribeiro, E. L. A. 2019. \\ Heritability estimation and genetic correlations \\ for mature weight, visual scores, and growth \\ traits in Nellore cattle. Revista Brasileira de \\ Zootecnia 48:e20170246. \\ https://doi.org/10.1590/rbz4820170246 \\ Copyright: This is an open access article \\ distributed under the terms of the \\ Creative Commons Attribution License \\ (http://creativecommons.org/licenses/by/4.0/), \\ which permits unrestricted use, distribution, \\ and reproduction in any medium, provided the \\ original work is properly cited.
}

\begin{abstract}
This study was intended to estimate the genetic associations between growth traits and visual scores with possible changes in mature weight (MW) in 397,900 Nellore animals. A bi-character analysis was performed to estimate the (co)variances and genetic parameters for MW, which comprises the following traits: conformation, finishing precocity, musculature at weaning (WC, WP, and WM) and yearling (YC, YP, and YM), birth weight (BW), weight from birth to weaning (WG), weight from weaning to yearling (YG), and final index (FIND). The observed mean MW was $417.6 \pm 56.2 \mathrm{~kg}$, and the direct genetic effect mean estimated heritability $\left(\mathrm{h}^{2}{ }_{\mathrm{a} 1}\right)$ of MW was 0.45 . Overall, the BW was $31.0 \pm 3.7 \mathrm{~kg}$, and the estimated $\mathrm{h}^{2}$ was 0.34 . The heritability estimate of the maternal additive genetic component $\left(\mathrm{h}^{2}{ }_{\mathrm{m} 2}\right)$ of BW was 0.07 . We calculated the mean WG to be $144.1 \pm 26.3$ and estimated the $\mathrm{h}^{2}{ }_{\mathrm{a} 2}$ as 0.18 and $\mathrm{h}_{\mathrm{m} 2}{ }_{2}$ as 0.07 . The value for $\mathrm{h}^{2}{ }_{\mathrm{a}} \mathrm{YG}(0.17)$ and YW (0.26) were also estimated. The heritability of the weaning WC (0.17), WP (0.19), and WM (0.17) and yearling YC (0.25), YP (0.27), and YM (0.25) were estimated using visual scores. The $\mathrm{h}^{2}{ }_{\mathrm{m}}$ values for weaning WC, WP, and WM (0.06) with visual scores were estimated. The genetic correlations between body weight (BoW) at YC and WC (0.62) were considered moderately high and positive. In addition, YP (0.18), YM (0.15), WP (0.13), and WM (0.14) were considered moderately low compared with MW. The genetic correlation between BW and FIND (0.38) was considered positive and moderate. The heritability estimation indicates that growth traits, visual scores, and weight of adult cows could be changed by selection. Cows that presented the highest $\mathrm{h}^{2}{ }_{\mathrm{a}}$ values for live weight responded rapidly to selection based on growth characteristics, visual scores, and FIND and might result in increased final MW.
\end{abstract}

Keywords: beef cattle, growth parameters, productive traits, selection

\title{
Introduction
}

There are many problems inherent to the production of beef cattle, including the low genetic potential of the herds, lack of adaptation to the environment, and inadequate management conditions, which can result in low productivity in the breeding systems. Between 1990 and 2009, the Brazilian cattle herd grew from the central part of Minas Gerais State (in the Southeast region) to the North of Goiás State (in the Midwest region). This growth is the result of favorable conditions, including external drivers 
and socioeconomic factors (McManus et al., 2016). The efficiency of beef production systems in Central Brazil can be further improved. In this region, the availability of natural resources favors commercial exploitation and low production costs. Therefore, improved knowledge of the potential of genetic resources would likely lead to increased productivity of beef cattle production.

To increase the productivity and profitability of cow-calf production systems, it is necessary to select beef heifers, thereby reducing the requirements for animal replacement based on management decisions (Aby et al., 2012; Santana et al., 2013). Therefore, estimates of the heritability for growth traits indicate that the phenotypic value of these traits can be used to demonstrate the direct additive genetic value. Increases in body weight gain during animal growth can be used as selection criteria to improve beef cattle efficiency. Indeed, to achieve adequate adult cow size, the mature weight (MW) of adult cows can be included in the selection indexes. However, MW is genetically correlated with young cow weight that allows weight changes to occur (Boligon et al., 2010).

The findings of multiple studies suggest that selection based on conformation, finishing precocity, and muscling visual scores (VS) can be effective, as heritability obtained for these characteristics are moderate and similar to those of growth characteristics (Koury Filho et al., 2010; Regatieri et al., 2011). Boligon et al. (2011) reported that the inclusion of VS in the selection indexes is crucial and important to predict the possible changes in relation to the mature size of beef cows. Therefore, we aimed to estimate the genetic associations between growth characteristics and VS with possible weight changes in Nellore cows.

\section{Material and Methods}

The data used in this study was provided by the Conexão Delta G breeding program for genetic improvement of Nellore cattle in Central Brazil. Live weight data for adult cows were collected from 40,340 animals born between 1990 and 2007 from a pedigree file composed of 397,900 animals in commercial herds distributed in the states of Bahia, Goiás, Mato Grosso, Mato Grosso do Sul, Minas Gerais, Paraná, São Paulo, and Tocantins.

$\mathrm{Bi}$-character analysis were performed to estimate the (co)variance components and genetic parameters of the MW character for birth weight (BW), conformation, finishing precocity, musculature at weaning (WC, WP, and WM) and at yearling (YC, YP and YM), birth weight gain at weaning (WG), weight from weaning to yearling (YG), and final index (FIND) (Table 1).

The VS for conformation (C), finishing precocity (P), and musculature (M) were given to each animal individually. These scores are relative to those of the contemporary group (CG) of animals, and the highest scores indicate a more marked presence of the character, as described by Severo (1994).

Table 1 - Percentage weights applied to the expected progeny differences of the characteristics included in the final index at yearling from the Delta G Connection database

\begin{tabular}{lc}
\hline Characteristic & Percentage weight (\%) \\
\hline Weight gain from birth to weaning & 25 \\
Weaning conformation & 4 \\
Weaning finishing precocity & 8 \\
Weaning musculature & 8 \\
Weight gain from weaning to yearling & 25 \\
Yearling conformation & 4 \\
Yearling finishing precocity & 8 \\
Yearling musculature & 8 \\
Scrotal circumference at yearling & 10 \\
\hline
\end{tabular}


The MW data of CG includes annotations for the animal herd, weighing year, season, and management group. For other characters, the CG were formed by animals of the same herd, year, and season of birth, sex, and management group. The data were subjected to a complete analysis of connectedness among CG. The degree of connectedness among CG was estimated through the genetic connections of each animal and all their common ancestors, according to Roso and Schenkel (2006). It was defined that a CG should have at least ten direct genetic ties to be considered connected, and all animals belonging to disconnected CG were excluded from the genetic analysis.

The bi-character animal model (Schaeffer, 2011) used in data analysis is described by the following equation:

$$
\left[\begin{array}{l}
\mathrm{y}_{1} \\
\mathrm{y}_{2}
\end{array}\right]=\left[\begin{array}{ll}
\mathrm{x}_{1} & 0 \\
0 & \mathrm{x}_{2}
\end{array}\right]\left[\begin{array}{l}
\mathrm{b}_{1} \\
\mathrm{~b}_{2}
\end{array}\right]+\left[\begin{array}{ll}
\mathrm{z}_{1} & 0 \\
0 & \mathrm{z}_{2}
\end{array}\right]\left[\begin{array}{l}
\mathrm{a}_{1} \\
\mathrm{a}_{2}
\end{array}\right]+\left[\begin{array}{ll}
\mathrm{W}_{1} & 0 \\
0 & \mathrm{~W}_{2}
\end{array}\right]\left[\begin{array}{l}
\mathrm{m}_{1} \\
\mathrm{~m}_{2}
\end{array}\right]\left[\begin{array}{ll}
\mathrm{S}_{1} & 0 \\
0 & \mathrm{~S}_{2}
\end{array}\right]\left[\begin{array}{l}
\mathrm{p}_{1} \\
\mathrm{p}_{2}
\end{array}\right]+\left[\begin{array}{l}
\mathrm{e}_{1} \\
\mathrm{e}_{2}
\end{array}\right],
$$

in which $\mathrm{y}_{1}=$ phenotypic observation vector for the MW characteristic; $\mathrm{y}_{2}=$ phenotypic observation vector for the second character of the pair of characters analyzed (BW, WG, WC, WP, WM, YG, YC, YP, YM, and $Y W) ; b_{1}=$ classificatory fixed effects vector for $C G$, body condition, pregnancy stage, and cow age (co)variable (linear and quadratic) at weighing day; $b_{2}=$ classificatory fixed effects vector for CG and calf (linear and quadratic) and cow (both linear and quadratic) age covariates on the growth characters and visual scores; $\mathrm{a}_{\mathrm{i}}=$ direct additive genetic effects for the $i(i=1,2)$ character vector; $\mathrm{m}_{\mathrm{i}}=$ additive maternal genetic effects for the $i$ character vector; $\mathrm{p}_{\mathrm{i}}=$ permanent maternal environmental effects for the $i$ character vector; and $\mathrm{e}_{\mathrm{i}}=$ residual random effects for the $i, \mathrm{X}_{\mathrm{i}}, \mathrm{Z}_{\mathrm{i}^{\prime}}, \mathrm{W}_{\mathrm{i}^{\prime}}, \mathrm{S}_{\mathrm{i}^{\prime}} \mathrm{X}_{\mathrm{i}}, \mathrm{Z}_{\mathrm{i}^{\prime}}, \mathrm{W}_{\mathrm{i}^{\prime}}$ and $\mathrm{S}_{\mathrm{i}}$ are the incidence matrices relating the observations of the $i$ character to the fixed, direct genetic, maternal genetic effects, and those of permanent maternal environment, respectively.

The additive maternal genetic and permanent maternal environmental effects were not considered in the BW statistical model. The estimates for direct additive $\left(\sigma_{\mathrm{a}}{ }^{2}\right)$ and maternal $\left(\sigma_{\mathrm{m}}{ }^{2}\right)$ genetic and maternal permanent $\left(\sigma_{\mathrm{p}}{ }^{2}\right)$ and residual $\left(\sigma_{\mathrm{e}}^{2}\right)$ environmental variances were expressed as proportions of the phenotypic variance $\left(\sigma_{\mathrm{t}}^{2}\right)$, and $\sigma_{\mathrm{t}}^{2}=\sigma_{\mathrm{a}}^{2}+\sigma_{\mathrm{m}}^{2}+\sigma_{\mathrm{am}}+\sigma_{\mathrm{p}}^{2}+\sigma_{\mathrm{e}}^{2}$.

The direct $\left(\mathrm{h}^{2}\right)$ and maternal $\left(\mathrm{h}^{2}\right)$ heritabilities and the maternal permanent $\left(\mathrm{p}^{2}\right)$ and residual $\left(\mathrm{e}^{2}\right)$ environmental effects were calculated by dividing the respective variances by the total variance according to the following equations: $\mathrm{h}_{\mathrm{a}}^{2}=\sigma_{\mathrm{a}}{ }^{2} / \sigma_{\mathrm{t}}^{2}, \mathrm{~h}_{\mathrm{m}}^{2}=\sigma_{\mathrm{m}}{ }^{2} / \sigma_{\mathrm{t}}^{2}, \mathrm{p}^{2}=\sigma_{\mathrm{p}}{ }^{2} / \sigma_{\mathrm{t}}^{2}$, and $\mathrm{e}^{2}=\sigma_{\mathrm{e}}{ }^{2} / \sigma_{\mathrm{t}}^{2}$, respectively. The correlation between the additive, direct, and maternal genetic effects were calculated as follows: $r_{a m}=\sigma_{a m} /\left(\sigma_{a} \sigma_{m}\right)$.

The (co)variance components were estimated using the restricted maximum likelihood (REML) method, and estimates of the effects included in the model were obtained using the DMU: Package for Analyzing Multivariate Mixed Models software according to Madsen and Jensen (2013).

\section{Results}

The average MW was $417.6 \pm 56.2 \mathrm{~kg}$ at $5.8 \pm 2.8$ years old (Table 2). The estimated heritability in the bi-character analyses of MW with the other characteristics studied was 0.45 , indicating that changes in the direction of the characteristics can be obtained by selection (Table 3). In addition, the $\mathrm{h}^{2}{ }_{\mathrm{a} 1}$ and $\mathrm{h}^{2}{ }_{\mathrm{a} 2}$ estimated heritability for BW returned high values of 0.47 and 0.34 , respectively (Table 3). The maternal heritability $\mathrm{h}_{\mathrm{m} 2}{ }_{2}(0.07)$ estimated for $\mathrm{BW}$ for growth characteristics after weaning was close to zero (Table 3). The mean WG estimate was $144.1 \pm 26.3 \mathrm{~kg}$ (Table 2), and $\mathrm{h}_{\mathrm{a} 2}{ }^{2}$ was 0.18 (Table 3).

The results obtained from the analysis of the BW-MW pairs showed a strong body condition score (BCS) effect on live weight variation (Figure 1). Animals that received BCS classification 1 (score 1) had $103.2 \mathrm{~kg}$ less body weight (BoW) compared with score 5 (Figure 1). Also, we reported a lower effect of the gestation length on the live weight variation (Figure 2). Cows during the beginning stage of pregnancy (from 1 to $72 \mathrm{~d}$ ) had $19.1 \mathrm{~kg}$ less BW compared with cows at late gestation (Figure 2).

The $\mathrm{h}^{2}$ a2 values estimated for the VS at weaning were $0.17,0.19$, and 0.17 for WC, WP, and WM, respectively (Table 4). The $\mathrm{h}^{2}$ a2 values estimated for the VS at yearling were $0.25,0.27$, and 0.25 for $\mathrm{YC}$, 
YP, and YM, respectively (Table 4). The genetic correlation between MW and VS at both weaning and yearling were moderately high and positive for conformation (0.62), whereas the finishing precocity and musculature scores were moderately low in our study (Table 4). The estimates for genetic correlation

Table 2 - Number of observations, means, and standard deviations (SD) for the analyzed data of Nellore cattle

\begin{tabular}{lcc}
\hline Characteristic & Sample size (n) & Mean \pm SD \\
\hline MW (kg) & 40,340 & $417.65 \pm 56.26$ \\
Age (years) & 40,340 & $5.88 \pm 2.88$ \\
BW (kg) & 241,471 & $31.00 \pm 3.77$ \\
WG (kg) & 339,963 & $144.12 \pm 26.38$ \\
WC (score) & 285,632 & $3.06 \pm 1.07$ \\
WP (score) & 285,640 & $3.17 \pm 1.10$ \\
WM (score) & 285,638 & $3.00 \pm 1.12$ \\
YG (kg) & 181,426 & $108.18 \pm 36.11$ \\
YC (score) & 186,293 & $3.04 \pm 1.03$ \\
YP (score) & 186,292 & $3.12 \pm 1.08$ \\
YM (score) & 186,285 & $2.89 \pm 1.09$ \\
YW (kg) & 137,562 & $286.69 \pm 45.94$ \\
FIND ${ }^{1}$ & 113,571 & $7.27 \pm 5.07$ \\
\hline
\end{tabular}

MW - mature weight; BW - birth weight; WG - weight gain from birth to weaning; WC - weaning conformation; WP - weaning finishing precocity; WM - weaning musculature; YG - weight gain after weaning; YC - yearling conformation; YP - yearling finishing precocity; YM - yearling musculature; YW - yearling weight; FIND - final index.

${ }^{1}$ The weighting factors of characteristics included in the index calculation were defined for a base equal to 10 (i.e., as if each animal was evaluated by 10 characteristics measured in their progenies). Thus, index 10 indicates that, on average, the animal is superior by one expected progeny difference standard deviation in every characteristic integrating the index.

Table 3 - Components of (co)variance obtained in the bi-character analysis for body weight with birth weight (BW), weaning gain (WG), yearling weight (YW), and mature weight (MW) of Nellore cattle (data shown as mean \pm SD)

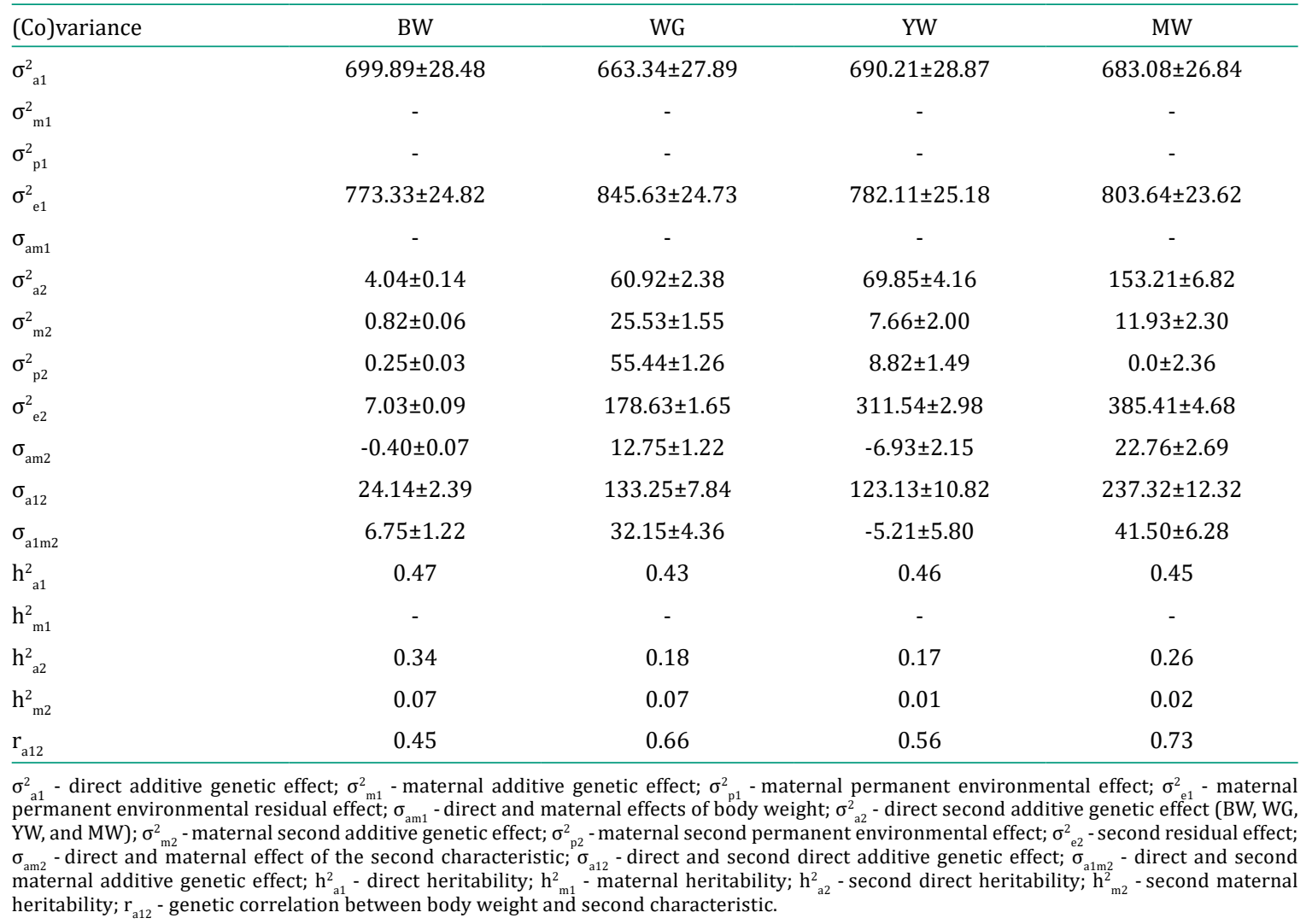




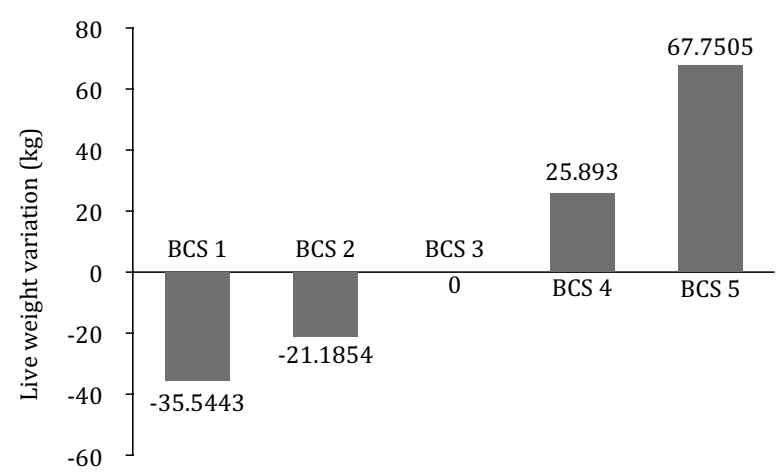

Body condition score (BCS)

Figure 1 - Effect of body condition score on live weight in Nellore cattle.

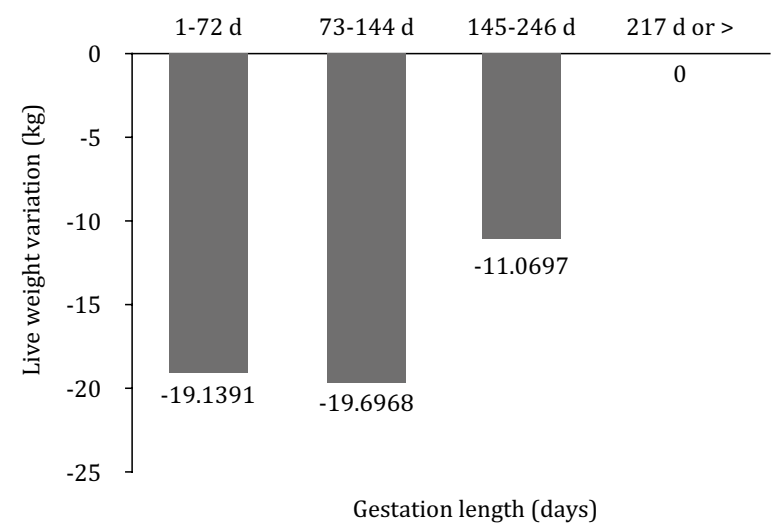

Figure 2 - Effect of gestation length on live weight in Nellore cattle.

Table 4 - Components of (co)variance obtained in bi-character analysis for body weight with weaning conformation (WC), weaning finishing precocity (WP), weaning musculature (WM), yearling conformation (YC), yearling finishing precocity (YP), yearling musculature (YM), mature weight (MW), and final index (FIND) of Nellore cattle (data shown as mean \pm SD)

\begin{tabular}{|c|c|c|c|c|c|c|c|c|}
\hline $\begin{array}{l}\text { (Co) } \\
\text { variance }\end{array}$ & WC & WP & WM & YC & YP & YM & MW & FIND \\
\hline$\overline{\sigma_{a 1}^{2}}$ & $653.40 \pm 28.20$ & $670.98 \pm 29.54$ & $672.40 \pm 29.62$ & $680.21 \pm 27.67$ & $679.63 \pm 29.35$ & $678.12 \pm 29.52$ & $683.08 \pm 26.84$ & $649.24 \pm 28.64$ \\
\hline$\sigma_{m 1}^{2}$ & - & - & - & - & - & - & - & - \\
\hline$\sigma_{\mathrm{p} 1}^{2}$ & - & - & - & - & - & - & - & - \\
\hline$\sigma^{2}{ }_{e 1}^{2}$ & $815.43 \pm 24.89$ & $794.01 \pm 25.86$ & $791.97 \pm 25.91$ & $797.89 \pm 24.26$ & $787.68 \pm 25.65$ & $787.98 \pm 25.80$ & $803.64 \pm 23.62$ & $794.36 \pm 25.24$ \\
\hline$\sigma_{\mathrm{am} 1}$ & - & - & - & - & - & - & - & - \\
\hline$\sigma_{\mathrm{a} 2}^{2}$ & $0.18 \pm 0.0$ & $0.22 \pm 0.0$ & $0.20 \pm 0.0$ & $0.22 \pm 0.01$ & $0.27 \pm 0.01$ & $0.26 \pm 0.01$ & $153.21 \pm 6.82$ & $21.49 \pm 0.13$ \\
\hline$\sigma_{m 2}^{2}$ & $0.06 \pm 0.0$ & $0.07 \pm 0.0$ & $0.081 \pm 0.0$ & $0.01 \pm 0.00$ & - & $0.01 \pm 0.0$ & $11.93 \pm 2.30$ & - \\
\hline$\sigma_{p 2}^{2}$ & $0.14 \pm 0.0$ & $0.15 \pm 0.0$ & $0.17 \pm 0.0$ & - & - & - & $0.00 \pm 2.36$ & - \\
\hline$\sigma_{\mathrm{e} 2}^{2}$ & $0.61 \pm 0.0$ & $0.67 \pm 0.0$ & $0.70 \pm 0.0$ & $0.65 \pm 0.00$ & $0.72 \pm 0.00$ & $0.75 \pm 0.0$ & $385.41 \pm 4.68$ & $0.53 \pm 0.05$ \\
\hline$\sigma_{\mathrm{am} 2}$ & $0.01 \pm 0.0$ & - & $0.11 \pm 0.0$ & - & - & - & $22.76 \pm 2.69$ & - \\
\hline$\sigma_{\mathrm{a} 12}$ & $6.86 \pm 0.47$ & $1.65 \pm 0.59$ & $1.69 \pm 0.58$ & $7.78 \pm 0.49$ & $2.56 \pm 0.55$ & $2.06 \pm 0.56$ & $237.32 \pm 12.32$ & $45.14 \pm 1.73$ \\
\hline$\sigma_{\mathrm{a} 1 \mathrm{~m} 2}$ & $1.67 \pm 0.26$ & $1.53 \pm 0.31$ & $1.39 \pm 0.31$ & $0.66 \pm 0.24$ & $0.74 \pm 0.27$ & $0.67 \pm 0.28$ & $41.50 \pm 6.28$ & - \\
\hline$h^{2}{ }^{2} 1$ & 0.44 & 0.45 & 0.45 & 0.46 & 0.46 & 0.46 & 0.45 & 0.44 \\
\hline $\mathrm{h}^{2}{ }_{\mathrm{m} 1}$ & - & - & - & - & - & - & - & - \\
\hline $\mathrm{h}^{2}{ }_{\mathrm{a} 2}$ & 0.17 & 0.19 & 0.17 & 0.25 & 0.27 & 0.25 & 0.26 & 0.97 \\
\hline $\mathrm{h}_{\mathrm{m} 2}^{2}$ & 0.06 & 0.06 & 0.06 & 0.01 & - & - & 0.02 & - \\
\hline$r_{\mathrm{a} 12}$ & 0.62 & 0.13 & 0.14 & 0.62 & 0.18 & 0.15 & 0.73 & 0.38 \\
\hline
\end{tabular}

$\sigma^{2}$ - direct additive genetic effect; $\sigma^{2}$ - maternal additive genetic effect; $\sigma^{2}$ - maternal permanent environmental effect; $\sigma^{2}$ - maternal permanent environmental residual effect; $\sigma_{\mathrm{am} 1}$ - direct and maternal effects of body weight; $\sigma_{\mathrm{a} 2}^{2}$ - direct second additive genetic effect (WC, WP, WM, YC, YP, YM, and MW); $\sigma_{\mathrm{m} 2}^{2}$ - maternal second additive genetic effect; $\sigma_{\mathrm{p} 2}^{2}$ - maternal second permanent environmental effect; $\sigma^{2}$ - second residual effect; $\sigma_{\mathrm{am} 2}$ - direct and maternal effect of the second characteristic; $\sigma_{\text {a12 }}$ - direct and second direct additive genetic effect; $\sigma^{2}{ }^{2}$ - direct and second maternal additive genetic effect; $\mathrm{h}^{2}{ }_{\mathrm{a1}}$ - direct heritability; $\mathrm{h}^{2}{ }_{\mathrm{m} 1}$ - maternal heritability; $\mathrm{h}^{2}{ }_{\mathrm{a} 2}$ - second direct heritability; $\mathrm{h}^{2}{ }_{\mathrm{m} 2}$ - second maternal heritability; $r_{a 12}$ - genetic correlation between body weight and second characteristic. 
between MW and growth characteristics were highly positive (0.73). The genetic correlation of MW with FIND was positive and moderate, estimated at 0.38 , which indicates that there is an influence of FIND on adult weight of the evaluated animals.

\section{Discussion}

The mean MW value was $417 \mathrm{~kg}$, obtained at a mean age of 5.8 years, which is lower than the values for Nellore cattle reported by Pedrosa et al. (2010) and Regatieri et al. (2011) (465.3 and $434.6 \mathrm{~kg}$, respectively). The estimated heritability of the bi-character analysis of MW in our study was 0.45 , which provides a high magnitude value, indicating that this characteristic examined in the present study is likely to be more useful during animal selection. The estimated heritability agrees with that reported by Pedrosa et al. (2010), but is higher than that reported by Rosa et al. (2001). In contrast, the estimated heritability value was lower than the 0.56 reported by Mercadante et al. (2004), and the 0.52 obtained by Nephawe et al. (2004). The higher values reported by these authors are because their data were from a single herd, which allowed environmental variations to be better modeled for genetic selection.

The pregnancy stages and BCS of cows (MW) were included in the analysis as selection criteria that might contribute to the genetic improvement of body composition. For example, cows that received $\mathrm{BCS}=1$ weighed $103.29 \mathrm{~kg}$ less than those that received score 5 , and pregnant cows in stage 1 (beginning of gestation) weighed less $19.13 \mathrm{~kg}$ than cows that were in stage 4 (end of gestation). Therefore, it can be assumed that the MW of Nellore cows is less affected by the gestation stage. The higher BCS effect on MW indicates that selection of animals with better body composition will be responsible for conformation changes that increase adult female size. Moreover, pre-weaning nutrition and average daily gain (ADG) are strategies to improve the economic and biological efficiency of cow-calf production systems, allowing anticipation of age at first breeding to determine puberty in heifers. There is a positive correlation between BW of dams and of their respective daughters, which can influence selection goals for replacement heifers, thereby achieving a significant improvement in growth efficiency of heifers (Barcellos et al., 2014; Walker et al., 2015; Pereira et al., 2017).

We observed a mean BW of $31 \mathrm{~kg}$ and estimated value of direct heritability of 0.34 , which is in line with data reported by Albuquerque and Meyer (2001) and Dias et al. (2005). Boligon et al. (2009) reported an estimated heritability of 0.25 and attributed this low value to the lower number of observations available at this age, which hampered the efforts to estimate the genetic variability for this characteristic. Our estimated $\mathrm{h}_{\mathrm{m} 2}$ value for BW was similar to that estimated by Lira et al. (2008) using a retrospective number of Nellore animals ( 0.07 and 0.09 , respectively). These low values indicate that the maternal environment has little influence on calf BW. Indeed, the mean BW values obtained in our study were slightly superior to those observed by Martins Filho et al. (1997) (27 kg) and similar to those obtained by Souza et al. (2010) and Boligon et al. (2009) (30 and $32 \mathrm{~kg}$, respectively).

Our estimated $\mathrm{h}^{2}{ }_{\mathrm{a} 2}$ value for WG (0.18) was similar to data reported by Laureano et al. (2011) and higher than the value obtained by Sarmento et al. (2003) (0.12). Our estimated $\mathrm{h}^{2}{ }_{\mathrm{a} 2}$ value for YG (0.17) was lower than that reported by Laureano et al. (2011) (0.23). We observed similar results in WG and YG; however, the selection at weaning (0.18) should be higher than at yearling (0.17). Our estimated $\mathrm{h}^{2}{ }_{\mathrm{a} 2}$ for MW (0.26) was similar to those of Albuquerque and Meyer (2001) and Laureano et al. (2011) (0.26 and 0.24 , respectively). The $\mathrm{h}_{\mathrm{m} 2}^{2}$ value in the present study (0.07), although low, should be taken into account, as it is an important parameter in the pre-weaning phase, in which milk production is one of the factors that contribute to the phenotypic value of the animals (Willham, 1980). The heritability estimated values for growth characteristics after weaning were close to zero, indicating a low influence of the maternal effect on these characteristics, even though Albuquerque and Meyer (2001) stated that the maternal effect is still present after weaning.

The heritability estimates for growth characters reveal that the phenotypic value for these characters can be used to indicate their direct additive genetic value. Increases in weight gain in these periods can 
be achieved by using these characteristics as selection criteria. Recently, Paterno et al. (2017) used data obtained from a Bayesian analysis that considered body structure, finishing precocity, and muscling as selection criteria in Nellore breeding programs and concluded that VS measured at weaning should be considered to decrease the generation interval and to assist with preselecting individuals. The estimates for genetic correlation between growth characteristics (BW, WG, YW, YG) were positively associated and ranged from 0.45 to 0.73 . Thus, our results suggest that selection for growth characteristics will result in weight increase at maturity.

The WC, WP, WM, YC, YP, and YM are within the expected range, as VS are considered as medium size given score 3 and assigned within the CG. The estimated $\mathrm{h}^{2}$ of VS for WC (0.17), WP (0.19), and WM (0.17) were higher compared with values found in the literature $(0.12,0.15$, and 0.12 , respectively) (Forni et al., 2007). Similarly, in Brangus animals, Costa et al. (2008) obtained $\mathrm{h}^{2}{ }_{\mathrm{a}}$ for $\mathrm{WC}$ (0.17), WP (0.16), and WM (0.15). The appropriate body size for beef cattle depends on the production and maintenance requirements (Rocha et al., 2003). The heritability estimate of 0.26 indicates that this trait is susceptible to changes through the selection of adult size in the Nellore breed, which predominates in the production systems of Central Brazil (Rosa et al., 2001). In addition to cow size, growth traits (measured at multiple ages) are often used in beef selection programs to identify the animals with the highest genetic potential for these traits. Animals with greater size usually have an increase in their growth curve, which results in reduction of the onset of maturity and accumulation of body fat, which might reflect a higher age at puberty (Perry and Cushman, 2013).

The $\mathrm{h}^{2}{ }_{\mathrm{a}}$ values estimated for YC (0.25), YP $(0.27)$, and YM $(0.25)$ were close to those estimated by Koury Filho et al. (2010) $(0.24,0.32$, and 0.27 , respectively) and those obtained by Regatieri et al. (2011) $\left(0.24,0.27\right.$, and 0.25 , respectively). The $\mathrm{h}^{2}$ a values estimated for precocity were higher compared with other VS values, in agreement with other studies performed in the Nellore herd (Forni et al., 2007; Koury Filho et al., 2009). This increased genetic variability of the characters might be a consequence of differences in conducting selection by different breeders (Koury Filho et al., 2009). The smaller heritability estimates found for $C$ at both weaning (WC) and yearling (YC) might be due to a subjective definition of the characteristic, which can lead evaluators to either different interpretations or a lower variability of the characteristic in the study population (Boligon et al., 2010).

The $\mathrm{h}_{\mathrm{m} 2}{ }^{2}$ values estimated for VS at both weaning and yearling were close to zero. Furthermore, the values obtained by Forni et al. (2007) [0.01 (YC), 0.01 (YD), and 0.03 (YM)] were even lower than those estimated in the present study. Although the values are low, the maternal genetic effect cannot be ignored in the analysis of the $\mathrm{C}, \mathrm{P}$, and $\mathrm{M}$ characteristics at weaning, as the direct heritability is overestimated if the maternal effect is ignored, especially for the gains until weaning (Meyer, 1992). These estimates indicate that VS should respond to individual selection and assume the same selection intensity at both ages. Indeed, the results of the present study demonstrate that selection at yearling should be higher than at weaning, thus explaining the tendency to gain more weight in subsequent ages, as proposed in the literature (Boligon et al., 2010).

The genetic correlations between MW and VS at both weaning (WC) and yearling (YC) were positive (0.62) for conformation. In contrast, the finishing precocity and musculature scores were moderately low in both studied periods. According to Boligon et al. (2011), the high genetic association between conformation and MW can be explained by the fact that the conformation scores are assigned according to the development of the animal at the time of its evaluation. Thus, larger and heavier animals tend to receive higher scores for this character at weaning and yearling. This can be attributed to a misunderstanding by the evaluators in relation to the conformation character. The lower values for genetic correlation with MW in both phases for both finishing precocity and musculature suggest that animals with higher scores for precocity and muscling do not necessarily present high mature weight in adulthood.

Regatieri et al. (2011) analyzed a sample from the same database used in the present study and observed values ranging from 0.21 to 0.35 for genetic correlation between MW and VS. These authors 
concluded that animals with early muscle development, finishing, and a better carcass conformation tend to have a greater weight at maturity, especially when evaluated at yearling. The genetic correlation between MW and FIND (0.38) was positive and moderate, indicating that FIND influences the adult weight of animals.

\section{Conclusions}

Selection of animals based on growth characteristics, muscling visual scores, and final index could result in an increase in adult mature weight of cows. However, monitoring the mature weight of cows by choosing animals with desirable characteristics, high indexes, and moderate estimates of genetic value for live weight and through mating, it should be possible to increase the production and productivity of the Nellore cattle in Brazil.

\section{Acknowledgments}

This study was supported by Conselho Nacional de Desenvolvimento Científico e Tecnológico (CNPq; Project CNPq/Universal No. 430900/2016-3) and Coordenação de Aperfeiçoamento de Pessoal de Nível Superior (CAPES; Project CAPES/PNPD).

\section{References}

Aby, B. A.; Aass, L.; Sehested, E. and Vangen, O. 2012. A bio-economic model for calculating economic values of traits for intensive and extensive beef cattle breeds. Livestock Science 143:259-269. https://doi.org/10.1016/j.livsci.2011.10.003

Albuquerque, L. G. and Meyer, K. 2001. Estimates of covariance functions for growth from birth to 630 days of age in Nelore cattle. Journal of Animal Science 79:2776-2789. https://doi.org/10.2527/2001.79112776x

Barcellos, J. O. J.; Pereira, G. R.; Dias, E. A.; McManus, C.; Canellas, L.; Bernardi, M. L.; Tarouco, A. and Prates, E. R. 2014 Higher feeding diets effects on age and liveweight gain at puberty in crossbred Nelore $\times$ Hereford heifers. Tropical Animal Health Production 46:953-960. https://doi.org/10.1007/s11250-014-0593-6

Boligon, A. A.; Albuquerque, L. G.; Mercadante, M. E. Z. and Lôbo, R. B. 2009. Herdabilidades e correlações entre pesos do nascimento à idade adulta em rebanhos da raça Nelore. Revista Brasileira de Zootecnia 38:2320-2326. https://doi.org/10.1590/S1516-35982009001200005

Boligon, A. A.; Albuquerque, L. G.; Mercadante, M. E. Z. and Lôbo, R. B. 2010. Study of relations among age at first calving, average weight gains and weights from weaning to maturity in Nellore cattle. Revista Brasileira de Zootecnia 39:746-751. https://doi.org/10.1590/S1516-35982010000400007

Boligon, A. A.; Mercadante, M. E. Z. and Albuquerque, L. G. 2011. Genetic associations of conformation, finishing precocity and muscling visual scores with mature weight in Nelore cattle. Livestock Science 135:238-243. https://doi.org/10.1016/j.livsci.2010.07.011

Costa, G. Z.; Queiroz, S. A.; Oliveira, J. A. and Fries, L. A. 2008. Estimativas de parâmetros genéticos e fenotípicos de escores visuais e de ganho médio de peso do nascimento a desmama de bovinos formadores da raça Brangus. ARS Veterinária 3:172-176.

Dias, L. T.; Albuquerque, L. G.; Tonhati, H. and Teixeira, R. A. 2005. Estimação de parâmetros genéticos para peso em diferentes idades para animais da raça Tabapuã. Revista Brasileira de Zootecnia 34:1914-1919. https://doi.org/10.1590/S1516-35982005000600015

Forni, S.; Federici, J. F. and Albuquerque, L. G. 2007. Tendências genéticas para escores visuais de conformação, precocidade e musculatura à desmama de bovinos Nelore. Revista Brasileira de Zootecnia 36:572-577. https://doi.org/10.1590/S1516-35982007000300008

Koury Filho, W.; Albuquerque, L. G.; Alencar, M. M.; Forni, S.; Silva, J. A. V. and Lôbo, R. B. 2009. Estimativas de herdabilidade e correlações genéticas para escores visuais, peso e altura ao sobreano em rebanhos da raça Nelore. Revista Brasileira de Zootecnia 38:2362-2367. https://doi.org/10.1590/S1516-35982009001200010

Koury Filho, W.; Albuquerque, L. G.; Forni, L. G.; Silva, J. A. V.; Yokoo, M. J. and Alencar, M. M. 2010. Estimativas de parâmetros genéticos para os escores visuais e suas associaç̃oes com peso corporal em bovinos de corte. Revista Brasileira de Zootecnia 39:1015-1022. https://doi.org/10.1590/S1516-35982010000500011

Laureano, M. M. M.; Boligon, A. A.; Costa, R. B.; Forni, S.; Severo, J. L. P. and Albuquerque, L. G. 2011. Estimativas de herdabilidade e tendências genéticas para características de crescimento e reprodutivas em bovinos da raça Nelore. Arquivo Brasileiro de Medicina Veterinária e Zootecnia 63:143-152. https://doi.org/10.1590/S0102-09352011000100022 
Lira, T.; Rosa, E. M. and Garnero, A. V. 2008. Parâmetros genéticos de características produtivas e reprodutivas em zebuínos de corte. Ciência Animal Brasileira 9:1-22. Available at: <https://www.revistas.ufg.br/vet/article/view/3655/3421>. Accessed on: Sept. 12, 2017.

Madsen, P. and Jensen, J. 2013. DMU Ver. 6, rel. 5.2 Available at: <http://dmu.agrsci.dk/DMU/Doc/Current/dmuv6_ guide.5.2.pdf>. Accessed on: Sept. 12, 2017.

McManus, C.; Barcellos, J. O. J.; Formenton, B. K.; Hermuche, P. M.; Carvalho, O. A. D.; Guimarães, R.; Gianezini, M.; Dias, E. A.; Lampert, V. N.; Zago, D. and Neto, J. B. 2016. Dynamics of cattle production in Brazil. Plos ONE 11:e0147138. https://doi.org/10.1371/journal.pone.0147138

Martins Filho, R.; Lobo, R. N. B.; Lima, F. A. M. and Villarroel, A. B. S. 1997. Parâmetros genéticos e fenotípicos de pesos e ganhos em pesos de bovinos zebus no Estado do Ceará. p.248-250. In: Anais da 34⿳亠丷a Reunião Anual da Sociedade Brasileira de Zootecnia. Juiz de Fora, MG, Brasil.

Mercadante, M. E. Z.; Razook, A. G.; Cyrillo, J. N. S. G. and Figueiredo, L. A. 2004. Efeito da seleção para crescimento na permanência de vacas Nelore no rebanho até cinco anos de idade. Revista Brasileira de Zootecnia 33:344-349. https://doi.org/10.1590/S1516-35982004000200010

Meyer, K. 1992. Variance components due to direct and maternal effects for growth traits of Australian beef cattle. Livestock Production Science 31:179-204. https://doi.org/10.1016/0301-6226(92)90017-X

Nephawe, K. A.; Cundiff, L. V.; Dikeman, M.E.; Crouse, J. D. and Van Vleck, L. D. 2004. Genetic relationship between sex-specific traits in beef cattle: Mature weight, weight adjusted for body condition score, height and body condition score of cows, and carcass traits of their steer relatives. Journal of Animal Science 82:647-653. https://doi.org/10.2527/2004.823647x

Paterno, F.; Buzanskas, M. E.; Koury Filho, M.; Lôbo, R. B. and Queiroz, S. A. 2017. Genetic analysis of visual assessment and body weight traits and their relationships with reproductive traits in Nellore cattle. Journal of Agricultural Science 155:679-687. https://doi.org/10.1017/S0021859617000028

Pedrosa, V. B.; Eler, J. P.; Ferraz, J. B. S.; Silva, J. A. V.; Ribeiro, S.; Silva, M. R. and Pinto, L. F. B. 2010. Parâmetros genéticos do peso adulto e características de desenvolvimento ponderal na raça Nellore. Revista Brasileira de Saúde e Produção Animal 11:104-113.

Pereira, G. R.; Barcellos, J. O. J.; Sessim, A. G.; Tarouco, J. U.; Feijó, F. D.; Braccini Neto, J.; Prates, E. R. and Canozzi, M. E. A. 2017. Relationship of post-weaning growth and age at puberty in crossbred beef heifers. Revista Brasileira de Zootecnia 46:413-420. https://doi.org/10.1590/s1806-92902017000500007

Perry, G. A. and Cushman, R. 2013. Effect of age at puberty/conception date on cow longevity. The Veterinary Clinics of North America: Food Animal Practice 29:579-590. https://doi.org/10.1016/j.cvfa.2013.07.011

Regatieri, I. C.; Boligon, A. A. and Albuquerque, L. G. 2011. Genetic analysis of visual scores and their relationships to mature female weigth in Nellore breed. Revista Brasileira de Zootecnia 40:100-105. https://doi.org/10.1590/S151635982011000100014

Rocha, E. D.; Andrade, V. J.; Euclides Filho, K.; Nogueira, E. and Figueiredo, G. R. 2003. Tamanho de vacas Nelore adultas e seus efeitos no sistema de produção de gado de corte. Arquivo Brasileiro de Medicina Veterinária e Zootecnia 55:474-479. https://doi.org/10.1590/S0102-09352003000400014

Rosa, A. N.; Lôbo, R. B.; Oliveira, H. N.; Bezerra, L. A. F. and Borjas, A. R. 2001. Peso adulto de matrizes em rebanhos de seleção da raça Nelore no Brasil. Revista Brasileira de Zootecnia 30:1027-1036. https://doi.org/10.1590/S151635982001000400017

Roso, V. M. and Schenkel, F. S. 2006. AMC - A computer program to assess the degree of connectedness among contemporary groups. p.27-26. In: Proceedings of the 8th World Congress on Genetics Applied to Livestock Production. Belo Horizonte, MG, Brazil.

Santana, M. L. Jr.; Eler, J. P.; Bignardi, A. B. and Ferraz, J. B. S. 2013. Genetic associations among average annual productivity, growth traits, and stayability: A parallel between Nelore and composite beef cattle. Journal of Animal Science 91:2566-2574. https://doi.org/10.2527/jas.2012-5856

Sarmento, J. L. R.; Pimenta Filho, E. C.; Ribeiro, M. N. and Martins Filho, R. 2003. Efeitos ambientais e genéticos sobre o ganho em peso diário de bovinos Nelore no estado da Paraíba. Revista Brasileira de Zootecnia 32:325-330. https://doi.org/10.1590/S1516-35982003000200010

Schaeffer, L. R. 2011. Multiple Traits. Animal Models - Course Notes. University of Guelph. Available at: <http://www.aps. uoguelph.ca/ lrs/abmodels/NOTES/multiple.pdf>. Accessed on: Sept. 12, 2017.

Severo, J. L. P. 1994. Manejo e controle de produção para a implantação de um programa de melhoramento genético de bovinos de corte. p.2-23. In: Bovinos de corte: seleção e cruzamento. GenSys Consultores Associados S/C Ltda., Porto Alegre.

Souza, J. C.; Salles, F. M.; Silva, L. O. C.; Mota, F. M.; Freitas, J. A.; Malhado, C. H. M. and Ferraz Filho, P. B. 2010. Avaliação de características produtivas em animais da raça Nelore por meio de análise multivariada. Revista Brasileira de Ciência Veterinária 17:99-103. https://doi.org/10.4322/rbcv.2014.152

R. Bras. Zootec., 48:e20170246, 2019 
Walker, R. S.; Martin, R. M. and Buttrey, B. 2015. Effects of residual feed intake and dam body weight on replacement heifer intake, efficiency, performance, and metabolic response. Journal of Animal Science 93:3602-3612. https://doi. org/10.2527/jas.2015-9040

Willham, R. L. 1980. Problems in estimating maternal effects. Livestock Production Science 7:405-418. https://doi. org/10.1016/0301-6226(80)90080-9 